Research Article

\title{
Genetic control of Eucalyptus urophylla and E. grandis resistance to canker caused by Chrysoporthe cubensis
}

\author{
Lúcio Mauro da Silva Guimarães ${ }^{1}$, Marcos Deon Vilela de Resende ${ }^{2}$, Douglas Lau ${ }^{3}$, \\ Leonardo Novaes Rosse ${ }^{4}$, Alexandre Alonso Alves ${ }^{1}$ and Acelino Couto Alfenas ${ }^{1}$ \\ ${ }^{1}$ Departamento de Fitopatologia/BIOAGRO, Universidade Federal de Viçosa, Viçosa, MG, Brazil. \\ ${ }^{2}$ Embrapa Florestas, Colombo, PR, Brazil. \\ ${ }^{3}$ Embrapa Trigo, Passo Fundo, RS, Brazil. \\ ${ }^{4}$ Veracel S.A., Eunápolis, BA, Brazil.
}

\begin{abstract}
Chrysophorte cubensis induced canker occurs in nearly all tropical and subtropical regions where eucalypts are planted, causing losses in both wood quality and volume productivity, especially so in the warmer and more humid regions of Brazil. The wide inter and intra-specific genetic variability of resistance to canker among Eucalyptus species facilitates the selection of resistant plants. In this study, we evaluated resistance to this pathogen in five Eucalyptus grandis $(\mathrm{G})$ and $15 \mathrm{E}$. urophylla $(\mathrm{U})$ trees, as well as in 495 individuals from 27 progenies derived from crosses between the trees. In the field, six-months-old test seedlings were inoculated with $C$. cubensis. Lesion length in the xylem and bark was measured eight months later. The results demonstrated that xylem lesions could preferentially be used for the selection of resistant clones. Eight trees $(7 \mathrm{U}$ and $1 \mathrm{G})$ were susceptible, and the remainder ( $8 \mathrm{U}$ and 4 G) resistant. Individual narrow and broad sense heritability estimates were 17 and $81 \%$, respectively, thereby suggesting that canker resistance is quantitative and highly dependent on dominance and epistasis.
\end{abstract}

Key words: genetic resistance, genetic breeding, eucalypt and interspecific hybrids.

Received: June 23, 2009; Accepted: February 23, 2010.

\section{Introduction}

Chrysophorte cubensis induced eucalypt canker is one of the most destructive diseases among plantation-raised Eucalyptus trees (Van Heerden and Wingfield, 2001). The disease, first reported by Bruner (1917) in Cuba, was initially attributed to Diaporthe cubensis Bruner. After the 1970's, occurrence was reported in various regions of the world, but mainly in South America (Hodges et al., 1979; Van der Merwe et al., 2001), Africa (Gibson, 1981; Wingfield et al., 1989; Nakabonge et al., 2006) and southeastern Asia (Sharma et al., 1985; Davison and Coates, 1991). Hodges (1980) proposed transferring the eucalypt canker fungus to Cryphonectria cubensis (Bruner) Hodges. However, recent studies involving comparative sequencing of the ITS (Internal Transcribed Spacer) region of ribosomal DNA and $\beta$-tubulin genes, revealed this fungus to be phylogenetically distinct from other species of Cryphonectria (Myburg et al., 2004). Gryzenhout et al., (2004), on describing the Chrysoporthe genera, and so as to accommodate this etiological agent therein, proposed the

Send correspondence to Acelino Couto Alfenas. Departamento de Fitopatologia/BIOAGRO, Universidade Federal de Viçosa, 36570-000 Viçosa, MG, Brazil. E-mail: aalfenas@ufv.br. name Chrysoporthe cubensis (Bruner) Gryzenh. \& M.J. Wingfield.

The disease is epidemiologically important in regions where the mean temperature is $\geq 23{ }^{\circ} \mathrm{C}$ and annual rainfall $\geq 1200 \mathrm{~mm}$ (Hodges et al., 1976; Alfenas et al., 1982; Sharma et al., 1985; Conradie et al., 1990). There are three basic symptoms of the canker in eucalypts. The first occurs in plants less than one year old. In this case, the infected plants often die as a consequence of stem girdling and cambium death. The second set of symptoms and signs occurs in trees two years old or more. This set is characterized by the appearance of sunken areas in the stem, cracking of the bark, either at the base of these sunken areas or along the stem, and external colonization of the bark surrounding the dead cambium. The third set of symptoms is the typical canker, a well-defined deep lesion or set of lesions surrounded by calluses. This occurs when a larger section of the cambium is dead, and the tree attempts to recover from the infection (Hodges et al., 1976).

The existence of inter and intra-specific genetic variability for canker resistance in eucalypts (Ferreira et al., 1977; Alfenas et al., 1983; Van Heerden and Wingfield, 2002), together with the development of large scale cloning in the 1980s, has lead to the control of the disease through 
the selection and cloning of resistant genotypes (Conradie et al., 1990; Wingfield, 1990; Seixas et al., 2004). On the other hand, it has been shown that the combination of favorable environmental conditions and genetic uniformity in clonal plantations may lead to significant losses by this canker, when employing susceptible clones (Van Heerden et $a l ., 2005)$. Disease monitoring in commercial and experimental plantations, the evaluation of genetic variability in a pathogen population, and the selection of resistant clones and parent trees for breeding programs, are all imperative for reducing potential losses. The aim of this study was to assess the resistance of E. grandis and E. urophylla parent trees and their progenies.

\section{Material and Methods}

\section{Plant material}

Five parent trees of $E$. grandis (G39, G45, G58, G93 e G547), 15 of E. urophylla (U1177, U1179, U1183, U1185, U1237, U1275, U1282, U1286, U1305, U1310, U1313, U1316, U1392, U1450, U1455), and 495 individuals from 27 progenies derived from crosses between selected parents of these two species, were prepared for resistance testing (Table 1). Ten rooted cuttings from each parent tree and seedlings of the progenies were transplanted to the field and outplanted at a $2.5 \times 2.5 \mathrm{~m}$ spacing. Test-site location was close to Eunápolis, Bahia, Brazil ( $\geq 1400 \mathrm{~mm}$ annual rainfall and $\pm 23{ }^{\circ} \mathrm{C}$ mean annual temperature). Ten plants from

Table 1 - Extent of xylem lesion in hybrid families of Eucalyptus grandis x E. urophylla inoculated with Chrysoporthe cubensis.

\begin{tabular}{|c|c|c|c|c|c|c|}
\hline \multirow[t]{2}{*}{ Progeny } & \multirow[t]{2}{*}{ Parent tree (resistance phenotype) } & \multirow{2}{*}{$\begin{array}{c}\mathrm{N}^{\circ} \text { of plants evaluated } \\
\text { per progeny }\end{array}$} & \multirow[t]{2}{*}{ Mean (cm) } & \multicolumn{2}{|c|}{ Lesion size } & \multirow[t]{2}{*}{ Stand. deviation } \\
\hline & & & & Maximum $(\mathrm{cm})$ & Minimum (cm) & \\
\hline & $\mathrm{RC}$ & 10 & 4.7 & 22 & 2 & 5.4 \\
\hline P09 & G39 (R) x U1450 (R) & 20 & 9.9 & 29 & 2 & 8.7 \\
\hline P20 & U1237 (R) x G93 (R) & 20 & 10.0 & 48 & 2 & 12.8 \\
\hline P11 & G45 (R) x U1450 (R) & 19 & 11.6 & 60 & 2 & 17.9 \\
\hline P18 & U1185 (R) x G83 (-) & 20 & 11.8 & 37 & 2 & 11.0 \\
\hline P05 & G39 (R) x U1275 (R) & 14 & 13.1 & 60 & 2 & 16.6 \\
\hline P08 & G39 (R) x U1313 (R) & 21 & 13.6 & 55 & 2 & 17.6 \\
\hline P26 & $\mathrm{U} 1310(\mathrm{~S})$ x G547 (S) & 21 & 14.3 & 60 & 2 & 16.6 \\
\hline P16 & U1185 (R) x G47 (-) & 19 & 14.5 & 60 & 2 & 13.4 \\
\hline P15 & U1179 (R) x G549 (-) & 18 & 15.8 & 40 & 2 & 12.0 \\
\hline P21 & U1286 (S) x G99 (-) & 19 & 17.3 & 60 & 2 & 16.5 \\
\hline P07 & G39 (R) x U1305 (S) & 16 & 17.4 & 60 & 2 & 19.2 \\
\hline P03 & G39 (R) x U1183 (S) & 21 & 17.6 & 60 & 2 & 15.9 \\
\hline P17 & U1185 (R) x G51 (-) & 19 & 18.4 & 60 & 2 & 17.7 \\
\hline $\mathrm{P} 02$ & G39 (R) x U1072 (-) & 20 & 18.6 & 62 & 2 & 15.7 \\
\hline $\mathrm{P} 10$ & G45 (R) x U1177 (R) & 19 & 20.4 & 63 & 2 & 21.3 \\
\hline \multirow[t]{2}{*}{ P04 } & G39 (R) x U1206 (-) & 19 & 21.9 & 54 & 2 & 20.0 \\
\hline & $\mathrm{SC}$ & 10 & 22.0 & 43 & 2 & 13.2 \\
\hline P27 & U1412 (-) x G549 (-) & 19 & 22.1 & 67 & 2 & 20.1 \\
\hline P25 & U1310 (S) x G93 (R) & 19 & 22.8 & 64 & 2 & 24.8 \\
\hline P23 & U1310 (S) x G51 (-) & 17 & 24.1 & 86 & 2 & 28.2 \\
\hline $\mathrm{P} 22$ & U1286 (S) x G504 (-) & 19 & 24.7 & 55 & 2 & 17.1 \\
\hline P14 & U1179 (R) x G547 (S) & 9 & 26.1 & 60 & 2 & 22.7 \\
\hline P06 & G39 (R) x U1282 (S) & 20 & 26.4 & 60 & 2 & 17.9 \\
\hline P01 & G39 (R) x U1034 (-) & 19 & 28.1 & 60 & 2 & 22.7 \\
\hline P12 & G47 (-) x U1455 (S) & 20 & 30.8 & 61 & 4 & 18.7 \\
\hline P13 & G99 (-) x U1316 (S) & 13 & 40.1 & 60 & 4 & 22.3 \\
\hline
\end{tabular}

(R) Resistant parent tree and (S) susceptible parent tree, based on a Tukey test (p=0.05) (Figure 1); and (-) parent tree resistance not evaluated. (G) E. grandis; (U) E. urophylla; (RC) resistant control and (SC) susceptible control. 
the 367 clone and ten from the 361 E. grandis hybrid were used as susceptible and resistant controls, respectively (based on Alfenas, AC - unpublished data). Six months after transplanting, the average breast height circumference was $10.5 \mathrm{~cm}$, large enough for inoculation with C. cubensis.

\section{Inoculation}

A single-spore culture of C. cubensis (LPF01), obtained from an E. grandis $\mathrm{x} E$. urophylla hybrid clone from Belo Oriente, Minas Gerais, Brazil, was used in all inoculations. The fungus was grown in Petri dishes $(9 \mathrm{~cm}$ in diameter) containing a $2 \%$ PDA (Potato-dextrose-agar) medium at $26 \pm 1{ }^{\circ} \mathrm{C}$, with a 12 -hour photoperiod. Seven millimeters diameter mycelial plugs of this inoculum were then taken from the plates with a cork borer, and inserted into the stem $60 \mathrm{~cm}$ above ground-level and just below the bark, in sixmonth-old test plants (as described in detail by Alfenas et al., 1983). The stem-inoculated area was then enclosed in a humid chamber, consisting of a moistened cotton ball placed below the inoculation point, both covered with plastic film. The plastic film was removed after 30 days.

\section{Resistance evaluation}

Eight months after inoculation, the plants were decapitated at $1.60 \mathrm{~m}$ above ground level, and the length of the bark lesion, caused as a response to inoculation, was measured. Subsequently the stem of each tree was vertically split with a chainsaw and the length of the xylem lesion measured.

\section{Statistical analysis}

The progenies, parents and control trees were all planted in a completely randomized design. Each experimental unit consisted of a single plant. Resultant data were analyzed with Genes ${ }^{\circledR}$ version 2007.0.0 (Cruz, 2006) and Selegen-Reml/Blup ${ }^{\circledR}$ (Resende, 2002) software packages. Parent trees that did not differ significantly from the resistant control (clone 361$)$ by the Tukey test $(\mathrm{p}=0.05)$ were considered resistant. In the analysis and estimation of genetic parameters, linear mixed models (REML/BLUP procedures, Restricted Maximum Likelihood/Best Linear Unbiased Prediction) were employed. The REML/BLUP adjustment was based on the following mixed model:

$$
y=X f+Z g+e,
$$

in which $y, f, g, e$ are the data, fixed effects (means of control plants and progenies), the genotypic effects in progeny and parent trees (random), and random error vectors, respectively, whereas $X$ and $Y$ are the incidence matrixes for $f$ and $g$, respectively. Fitting this model to the experiment, with both progeny and parent trees, enabled estimating variance components (by REML) and broad and narrow sense heritabilities.
The following variance structures and relations were obtained through separate analysis of the full-sib experiment:

(i) Genetic variance among full-sib families: $\sigma_{F S}^{2}$.

(ii) Full-sib family mean heritability: $h_{F S M}^{2}=\sigma_{F S}^{2} /\left(\sigma_{F S}^{2}+\sigma_{W F S}^{2} / N\right)$, where $\sigma_{W F S}^{2}$ is within family individual phenotypic variation and $N$ is the number of plants per family.

(iii) Accuracy of family selection: $\left(h_{F S M}^{2}\right)^{1 / 2}$.

(iv) Coefficient of genotypic variation among progenies: $\operatorname{CVg}(\%)=100^{*}\left(\sigma_{F S}^{2}\right)^{1 / 2} /($ General mean $)$.

(v) Coefficient of residual variation: $C V e(\%)=100 *\left(\sigma_{W F S}^{2}\right)^{1 / 2} /($ General mean $)$.

(vi) Within full-sib family individual broad sense heritability: $h_{W F S}^{2}=\sigma_{F S}^{2} / \sigma_{W F S}^{2}$, assuming that between and within family genetic variances are approximately the same.

Using a separate analysis for the cloned parents experiment, the following variance structures and relations were obtained:

(vii) Genetic variance among cloned parents: $\sigma_{C P}^{2}=\sigma_{A}^{2}+\sigma_{D}^{2}$.

(viii) Individual broad sense heritability: $h_{b}^{2}=\sigma_{C P}^{2} / \sigma_{F C P}^{2}$, where $\sigma_{F C P}^{2}$ is the individual phenotypic variation for parents.

Furthermore, joint analysis of both experiments (cloned parents and full-sib families) revealed the possibility of estimating additive genetic variance $\left(\sigma_{A}^{2}\right)$ by its isolation from the sum of both itself and dominance variance. The three types of covariance between relatives (full-sibs, cloned parents and parent-offspring) were used simultaneously for estimating $\left\{\sigma_{A}^{2}\right\}$ by using residual maximum likelihood (REML). Specifically, the following estimates were obtained:

(ix) Additive genetic variance from joint analysis: $\hat{\sigma}_{A}^{2}$.

(x) Dominance genetic variance also from joint analysis: $\hat{\sigma}_{D}^{2}$.

(xi) Narrow-sense individual heritability $h_{n}^{2}=\hat{\sigma}_{A}^{2} / \sigma_{F J A}^{2}$, where $\sigma_{F J A}^{2}$ is individual phenotypic variation from joint analysis.

(xii) Broad-sense individual heritability from joint analysis: $h_{b j}^{2}=\left(\hat{\sigma}_{A}^{2}+\hat{\sigma}_{D}^{2}\right) / \sigma_{F J A}^{2}$.

The effects of segregation resulting from crossing highly heterozygous individuals were estimated by the difference between the mean of clonally analyzed parent trees and the mean of each cross involving the very same parent trees. These effects provide estimates of the depression by segregation resulting in the reduction in character average. This can be understood as the loss of heterosis, which may occur when crossing individuals that are predominantly heterozygotes. The genotypic mean values of the parent trees (assessed clonally) used in calculations also include the effects of dominance, and not only the additive effects 
that would be expected if parent trees were assessed seminally, as is common in annual crop breeding.

\section{Results}

Bark and sapwood symptoms were typical of the disease through natural infection (Figure 1). The colonization of C. cubensis in host tissues was confirmed by re-isolating the fungus on PDA. The correlation between the length of bark and xylem lesions in parent trees was virtually nil (0.09), whereas in progeny this was 0.68 , with a similar trend for average length (Table 1).

G93 was the most resistant among the parent trees assessed, with a mean xylem lesion length inferior to that of resistant control (RC) (Figure 2). Besides G93, the parent trees U1179, U1275, U1313, U1450, U1237, G58, U1392, G45, G39, U1177 and U1185 were considered resistant, since lesion lengths did not differ statistically from those of RC. The remaining parent trees (U1316, U1286, U1455, U1183, U1310, G547, U1282 and U1305) were susceptible, and in the case of U1183, U1310, G547, U1282 and U1305, mean xylem lesion lengths even exceeding those of susceptible control (SC) (Figure 2). All progenies segregated for resistance; however, none of them had a mean xylem lesion size below the mean of the resistant control $(4.7 \mathrm{~cm})$ (Table 1). Furthermore, in ten progenies (P13,

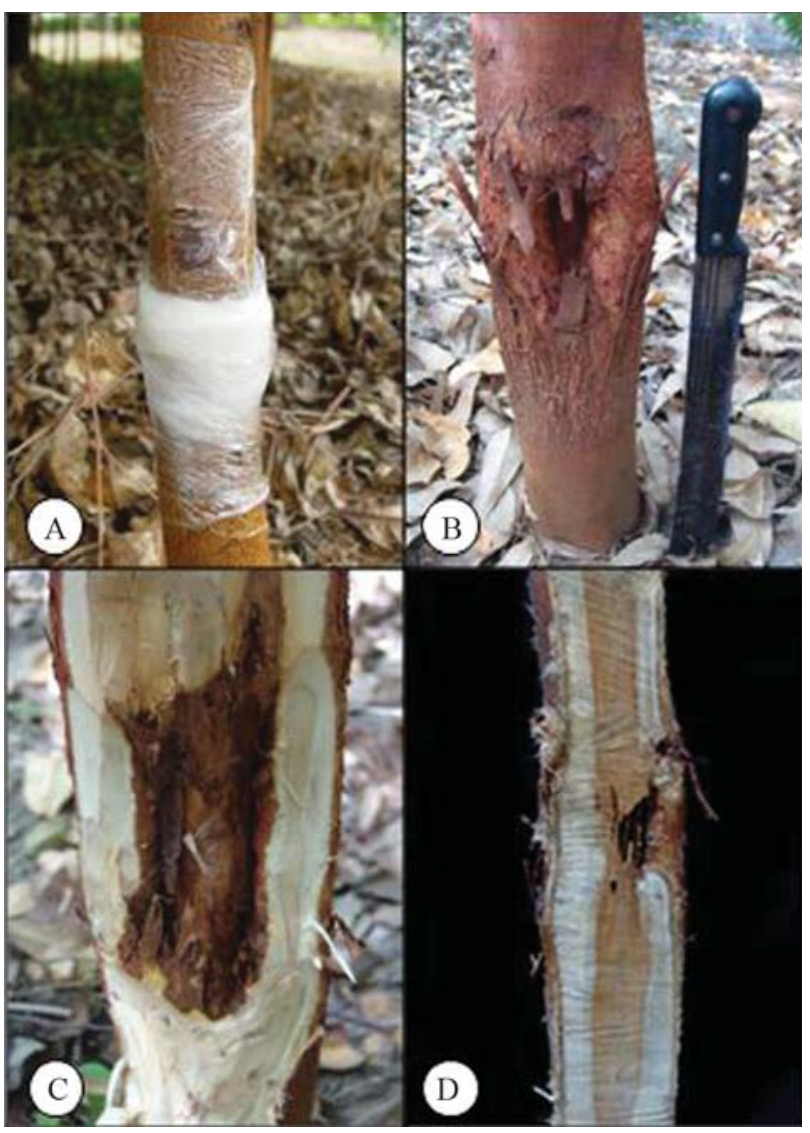

Figure 1 - (A) Moist chamber, (B) typical canker, (C) bark lesion, and (D) xylem lesion.
P12, P01, P06, P14, P22, P23, P19, P25 and P27) lesions were larger than in susceptible control $(22 \mathrm{~cm})$ (Table 1). In the six progenies (P09, P20, P11, P18, P05 and P08) from crosses between the resistant parent trees, mean xylem lesion sizes were the lowest (Table 1).

The estimates of individual heritability in a narrow (inter-specific level) and broad (intra-specific level) sense were $17 \%$ and $80 \%$, respectively (Table 2 ). There was a large genotypic variation among families (genotypic variation coefficient equal to $39 \%$ ), thereby indicating high heritability (65\%) and accuracy ( $81 \%)$ for selection among families. There is also some genetic variability for selection

Table 2 - Estimates of genetic parameters (variance components, heritabilities and coefficients of genetic variation) of E. grandis $x$ E. urophylla families for canker (Chrysoporthe cubensis) resistance, assessed by measuring xylem lesion length $(\mathrm{cm})$.

\begin{tabular}{lc}
\hline Genetic parameters & Values \\
\hline Genotypic variance among full-sib progenies & 30.40 \\
Genotypic variance among cloned parent trees & 45.29 \\
Individual phenotypic variance for progenies & 360.10 \\
Individual phenotypic variance for parent trees & 55.88 \\
Individual narrow sense heritability & $0.17 \pm 0.07$ \\
Individual broad sense heritability & $0.80 \pm 0.25$ \\
Individual phenotypic variance within progenies & 329.70 \\
Individual heritability within progenies & 0.08 \\
Heritability of progeny means & 0.65 \\
Accuracy of progeny means & 0.81 \\
Genotypic variation coefficient among progenies (\%) & 39.38 \\
Residual variation coefficient (\%) & 29.00 \\
Relative variation coefficient (\%) & 1.36
\end{tabular}

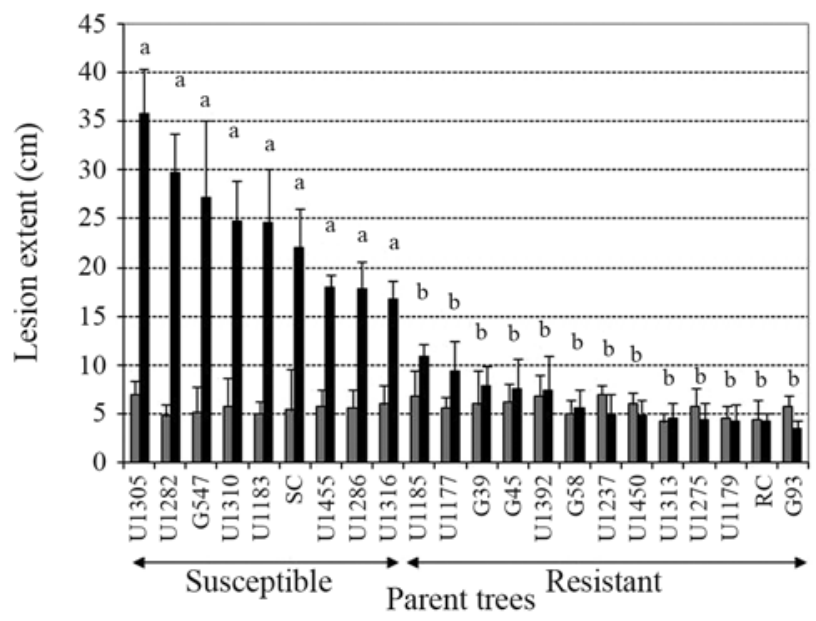

Figure 2 - Mean and standard deviation for extension of bark (gray) and xylem (black) lesions in parent trees of Eucalyptus grandis $(\mathrm{G})$ and E. urophylla (U) inoculated with Chrysoporthe cubensis. SC - susceptible control and $\mathrm{RC}$ - resistant control. Parent trees followed by the same letter did not differ by Tukey test $(\mathrm{p}=0.05)$. Parent trees were considered resistant when they did not differ statistically from resistant control. 
within families, as corroborated by the estimate $(8 \%)$ for heritability (Table 3). Estimates of heterosis loss or segregation effect in crosses between highly resistant heterozygous individuals were $78 \%$ on an average (Table 3 ).

\section{Discussion}

In view of the correlations encountered between the extent of lesions in bark and xylem alike (in the evaluated progenies), the method of inoculation used in this study proved to be appropriate for detecting resistance variability in the Eucalyptus spp. x C. cubensis pathosystem. In xylem, these lesions were more extensive, thus constituting the preferential criterion when selecting resistant clones. Nevertheless, heritability of lesion extent in bark in both experiments (parent trees and progenies) tended to zero, thereby inferring that this variable is inappropriate for genotypic discrimination.

This study revealed wide genetic variation for resistance in E. grandis and E. urophylla, thereby corroborating previous results (Ferreira et al., 1977; Alfenas et al., 1983; Van Heerden and Wingfield, 2002). Twelve out of the twenty parent trees tested were resistant. This high number of resistant parents probably reflects the intense selection for resistance to this disease that has taken place over the last few years (Van Zyl and Wingfield, 1999). It is noteworthy that these parents possess not only favorable alleles for resistance, since there was segregation in their progenies, but also that this trait can be transmitted through crossing with other resistant parents.

When assessing the nature and magnitude of those gene effects controlling a specific character, it is important to select and predict the behavior of hybrid generations and segregating populations. An estimation of the proportion of variability attributed to additive, dominant and epistatic effects is crucial, since the relative importance of these factors exerts a strong influence on genetic breeding programs. However, although the eucalypt canker is a disease of recognized importance, there are only a few studies aiming to obtain genetic information for resistance to this disease. In the present case, estimates of individual heritability in the narrow (inter-specific level) and broad (intra-specific level) sense were equivalent to $17 \%$ and $81 \%$, respectively, thus allowing the following inferences: (i) due to the low level of additive heritability and high level of broad sense heritability, breeding for eucalypt canker resistance may be achieved mainly by the selection and cloning of highly resistant genotypes, (ii) this resistance is probably a multigenic character; and (iii) this character exhibits high allelic dominance, or epistasis, given the wide distance between the values of the two heritabilities.

Additive genetic determination of resistance was $17 \%$, and of dominance and epistasis $64 \%$. Borges and Brune (1981), when using data from natural infection, also studied the heritability of resistance to eucalypt canker in half-sib families of $E$. grandis. However, according to these authors, heritability was of reasonable magnitude (0.65), with values in the narrow and broad sense close to one another. The results here are quite distinct from those of Borges and Brune (1981), indicating that genetic control of the character may vary between different sources of resistance. These contrasts may also be partially attributed to

Table 3 - Genotypic values (GV) of families and parent trees of Eucalyptus grandis (G) and E. urophylla (U), and values for segregation effects (loss of heterosis for resistance) of crosses involving two parents that were evaluated for resistance to eucalypt canker caused by Chrysoporthe cubensis by measuring the extent of xylem lesion $(\mathrm{cm})$.

\begin{tabular}{|c|c|c|c|c|c|c|c|}
\hline Female parent & Male parent & Family GV & Female parent GV & Male parent GV & Aver. GV of the PT* & Loss of heterosis & Loss of heterosis $(\%)$ \\
\hline G39 & U1450 & $12.91 * *$ & 7.97 & 6.64 & 7.30 & -5.61 & -76.81 \\
\hline U1237 & G93 & 12.94 & 6.64 & 6.02 & 6.33 & -6.62 & -104.56 \\
\hline G45 & U1450 & 14.14 & 7.88 & 6.64 & 7.26 & -6.88 & -94.83 \\
\hline G39 & U1313 & 15.38 & 7.97 & 6.55 & 7.26 & -8.12 & -111.95 \\
\hline G39 & U1275 & 15.58 & 7.97 & 6.46 & 7.21 & -8.37 & -116.02 \\
\hline U1310 & G547 & 15.87 & 15.49 & 16.55 & 16.02 & 0.15 & 0.92 \\
\hline U1310 & G58 & 16.39 & 15.49 & 6.99 & 11.24 & -5.15 & -45.77 \\
\hline G39 & U1183 & 18.11 & 7.97 & 22.52 & 15.24 & -2.87 & -18.85 \\
\hline G39 & U1305 & 18.14 & 7.97 & 20.36 & 14.16 & -3.97 & -28.05 \\
\hline G45 & U1177 & 20.06 & 7.88 & 8.67 & 8.28 & -11.78 & -142.4 \\
\hline U1310 & G93 & 21.65 & 15.49 & 6.02 & 10.75 & -10.89 & -101.27 \\
\hline U1179 & G547 & 22.65 & 6.37 & 16.55 & 11.46 & -11.19 & -97.59 \\
\hline G39 & U1282 & 24.14 & 7.97 & 17.71 & 12.84 & -11.31 & -88.09 \\
\hline Mean & 17.54 & 9.47 & 11.36 & 10.41 & -7.12 & -78.49 & \\
\hline
\end{tabular}

*Average genotypic value of parent trees.

**Higher values indicate higher susceptibility to the disease. 
disease escape, since Borges and Brune (1981) only evaluated naturally infected plants.

These issues should be carefully considered in breeding programs, for the more efficient selection of resistant clones. We found that the mean genotypic values of progeny as regards to xylem canker length exceeded those of parents, thereby indicating an increase in susceptibility. The loss of heterosis effect (78\%) may be explained by the presence of allelic dominance towards greater resistance to canker. Thus, crosses between superior heterozygous genotypes cause, on an average, a decrease of $50 \%$ in the total contribution of heterozygous loci to the character, possibly explaining the observed depression by segregation. Another possibility, and which may occur simultaneously, is the 'break', through hybridization, of favorable epistatic combinations for resistance in pure species. These epistatic combinations involve favorable polygenic blocks established during the long evolutionary process of the species and result in a co-evolution of genes. In temperate climates, inter-specific hybridization of eucalypt species has resulted in greater susceptibility to diseases in hybrids (Borralho, 2007).

Due to the wide genetic variation for canker resistance in E. grandis and E. urophylla, the introduction of resistant parent trees into ongoing breeding programs may increase the chances of obtaining disease resistant clones at the end of the selection program. The results of our study also reinforce the need for using artificial inoculation with C. cubensis, when selecting pathogen-resistant parent trees and progenies of Eucalyptus spp. Furthermore, they also highlight the importance of cloning resistant genotypes for disease control. Although we used only one isolate of $C$. cubensis in this study, others have disclosed diversity in the pathogen population (Van Zyl et al., 1998) and the existence of specific pathogen $\mathrm{x}$ host interactions, resulting in differential interactions between eucalypts clones and $C$. cubensis isolates (Alfenas et al., 1983; Van Heerden et al., 2005). Therefore, isolates with a broader virulence spectrum should be used in future assays for identifying resistant eucalypt clones.

\section{Acknowledgments}

The authors would like to thank the Brazilian National Research Council, $\mathrm{CNPq}$, for the fellowship grant and Veracel SA, for providing parent trees and progenies, as well as financial support for this work, especially to David Evandro Fernandes and Sézar Augusto. We would also like to thank Dr. Phil Cannon (USDA Forest Service) for reviewing the manuscript, and Marisângela R. Santos, Leonardo S. S. Oliveira, Edival A. V. Zauza, Natália R. Fonseca and Ricardo Martins for their technical assistance.

\section{References}

Alfenas AC, Hubbes M and Couto L (1982) Effect of phenolic compounds from Eucalyptus on the mycelial growth and conidial germination of Cryphonectria cubensis. Can J Bot 60:2535-2541.

Alfenas AC, Jeng R and Hubbes M (1983) Virulence of Cryphonectria cubensis on Eucalyptus species differing in resistance. Eur J Plant Pathol 13:197-205.

Borges RCG and Brune A (1981) Estudo da herdabilidade quanto à resistência a Diaporthe cubensis em Eucalyptus grandis W. Hill ex Maiden. Revista Árvore 5:115-120 (Abstract in English).

Borralho N (2007) Melhoramento genético do Eucalipto: Duas histórias com o mesmo fim. In: Anais do XI Simpósio de Atualização em Genética e Melhoramento de Plantas: Genética e Melhoramento de Plantas Perenes. GEN/UFLA, Lavras, pp 4-26.

Bruner SC (1917) Una enfermedad gangrenosa de los eucaliptos. Boletine 37:1-38.

Conradie E, Swart WJ and Wingfield MJ (1990) Cryphonectria canker of Eucalyptus, an important disease in plantation forestry in South África. S Afr For J 159:43-49.

Cruz CD (2006) Programa Genes: Biometria. Editora UFV, Viçosa, $382 \mathrm{pp}$.

Ferreira FA, Reis MS, Alfenas AC and Hodges CS (1977) Avaliação da resistência de Eucalyptus spp ao cancro causado por Diaporthe cubensis Bruner. Fitopatol Bras 2:225-241(Abstract in English).

Davison EM and Coates DJ (1991) Identification of Cryphonectria cubensis and Endothia gyrosa from eucalypts in Western Australia using isozyme analysis. Australas Plant Pathol 20:157-160.

Gibson IAS (1981) A canker disease of Eucalyptus new to Africa. Forest Gen Res Inf 10:23-24.

Gryzenhout MH, Myburg NA, Van der Merwe BD, Wingfield BD and Wingfield MJ (2004) Chrysoporthe, a new genus to accommodate Cryphonectria cubensis. Stud Mycol 50:119142.

Hodges CS (1980) The taxonomy of Diaporthe cubensis. Mycologia 72:542-548.

Hodges CS, Reis MS, Ferreira FA and Heffling JDM (1976) O cancro do eucalipto causado por Diaporthe cubensis Bruner. Fitopatol Bras 1:129-169 (Abstract in English).

Hodges CS, Geary TF and Cordell CE (1979) The occurrence of Diaporthe cubensis on Eucalyptus in Florida, Hawaii and Puerto Rico. Plant Dis 63:216-220.

Myburg H, Gryzenhout M, Wingfield BD, Wingfield MJ and Stipes RJ (2004) A reassessment of the fungal genera Cryphonectria and Endothia based on DNA sequence data. Mycologia 96:990-1001.

Nakabonge G, Roux J, Gryzenhout M and Wingfield MJ (2006) Distribution of chrysoporthe canker pathogens on Eucalyptus and Syzygium spp. in eastern and southern Africa. Plant Dis 90:734-740.

Resende MDV (2002) Genética Biométrica e Estatística no Melhoramento de Plantas Perenes. Embrapa Informação Tecnológica, Brasília, 975 pp.

Seixas CDS, Barreto RW, Alfenas AC and Ferreira FA (2004) Cryphonectria cubensis on an indigenous host in Brazil: A possible origin for eucalyptus canker disease? Mycologist 18:39-45. 
Sharma JK, Mohanan C and Florence EJM (1985) The occurrence of cryphonectria canker disease of Eucalyptus in Kerala, India. Ann Appl Biol 106:265-276.

Van der Merwe NA, Myburg H, Wingfield BD, Rodas C and Wingfield MJ (2001) Identification of Cryphonectria cubensis from Colombia based on rDNA sequence data. S Afr J Sci 97:295-296.

Van Heerden SW and Wingfield MJ (2001) Genetic diversity of Cryphonectria cubensis isolates in South Africa. Mycol Res 105:94-99.

Van Heerden SW and Wingfield MJ (2002) Effect of environment on the response of Eucalyptus clones to inoculation with Cryphonectria cubesis. For Pathol 32:395-402.

Van Heerden SW, Amerson HV, Preisig O, Wingfield BD and Wingfield MJ (2005) Relative pathogenicity of Crypho- nectria cubensis on Eucalyptus clones differing in their resistance to C. cubensis. Plant Dis 89:659-662.

Van Zyl LM and Wingfield MJ (1999) Wound response of Eucalyptus clones after inoculation with Cryphonectria cubensis. Eur J For Pathol 29:161-167.

Van Zyl LM, Wingfield MJ, Alfenas AC and Crous PW (1998) Population diversity among Brazilian isolates of Cryphonectria cubensis. For Ecol Manage 112:41-47.

Wingfield MJ (1990) Current status and future prospects of forest pathology in South Africa. S Afr J Sci 86:60-62.

Wingfield MJ, Swart WJ and Abear BJ (1989) First record of cryphonectria canker of Eucalyptus in South Africa. Phytophylactica 21:311-313.

Associate Editor: Márcio de Castro Silva Filho

License information: This is an open-access article distributed under the terms of the Creative Commons Attribution License, which permits unrestricted use, distribution, and reproduction in any medium, provided the original work is properly cited. 